\title{
Identification of a PET Radiotracer for Imaging of the Folate Receptor- alpha - A Potential Tool to Select Patients for Targeted Tumor Therapy
}

Patrycja Guzik ${ }^{1}$, Hsin-Yu Fang ${ }^{1}$, Luisa M. Deberle ${ }^{1}$, Martina Benešová ${ }^{1,2}$, Susan Cohrs ${ }^{1}$, Silvan D. Boss ${ }^{2}$, Simon M. Ametamey ${ }^{2}$, Roger Schibli ${ }^{1,2}$, Cristina Müller*,1,2

${ }^{1}$ Center for Radiopharmaceutical Sciences ETH-PSI-USZ, Paul Scherrer Institute, Villigen-PSI, Switzerland

${ }^{2}$ Department of Chemistry and Applied Biosciences, ETH Zurich, Zurich, Switzerland

\section{E-Mail addresses:}

patrycja.guzik@psi.ch; hy.fang11@gmail.com; luisa.deberle@psi.ch; martina.benesova@t-online.de; susan.cohrs@psi.ch; silvanboss@hotmail.com; simon.ametamey@pharma.ethz.ch; roger.schibli@psi.ch; cristina.mueller@psi.ch

\section{* Correspondence to:}

Cristina Müller, $\mathrm{PhD}, \mathrm{PD}$

Center for Radiopharmaceutical Sciences ETH-PSI-USZ

Paul Scherrer Institute

5232 Villigen-PSI

Switzerland

e-mail: cristina.mueller@psi.ch

phone: $\quad+41-56-3104454 \quad$ fax: $\quad+41-56-3102849$

ORCID: https://orcid.org/0000-0001-9357-9688 


\section{First author:}

Patrycja Guzik, PhD student

Center for Radiopharmaceutical Sciences ETH-PSI-USZ

Paul Scherrer Institute

5232 Villigen-PSI

Switzerland

e-mail: patrycja.guzik@psi.ch

phone: $\quad+41-56-3102847$

Running title: FR $\alpha$-selective PET imaging

Word count of the manuscript: 5333 words 


\section{ABSTRACT}

The aim of this study was to identify a folate receptor-alpha (FR $\alpha)$-selective PET agent, potentially suitable for the selection of patients that could profit from FR $\alpha$-targeted therapies. The $6 R$ - and $6 S$-isomers of ${ }^{18} \mathrm{~F}$ aza-5-methyltetrahydrofolate (MTHF) were assessed regarding their binding to the FR $\alpha$ and FR $\beta$, expressed on cancer and inflammatory cells respectively, and compared to ${ }^{18} \mathrm{~F}-\mathrm{AzaFol}$, the folic acid-based analogue. Methods FR selectivity was investigated using FR $\alpha$-transfected (RT16) and FR $\beta$-transfected (D4) CHO cells. The cell uptake of ${ }^{18} \mathrm{~F}$-folate tracers was investigated and receptor-binding affinities were determined with the non-radioactive analogues. In vitro autoradiography of the ${ }^{18} \mathrm{~F}$-folate tracers was performed using RT16 and D4 tissue sections. Biodistribution studies and PET/CT imaging of the radiotracers were performed with mice bearing RT16 and D4 xenografts.

Results The uptake of ${ }^{18}$ F-6R-aza-5-MTHF into RT16 cells was high (62 $\pm 10 \%$ of added activity) but much lower when using D4 cells ( $5 \pm 2 \%)$. FR $\alpha$ selectivity of ${ }^{18} \mathrm{~F}-6 R$-aza-5-MTHF was further demonstrated by its $\sim 43$-fold higher binding affinity to the $\mathrm{FR} \alpha\left(\mathrm{IC}_{50}=1.8 \pm 0.1 \mathrm{nM}\right)$ than to the $\mathrm{FR} \beta\left(\mathrm{IC}_{50}=77 \pm 27 \mathrm{nM}\right)$. The uptake of ${ }^{18} \mathrm{~F}-6 S$-aza-5-MTHF and ${ }^{18} \mathrm{~F}$-AzaFol was equal in both cell lines $(52-70 \%)$ and similar affinities to the $\mathrm{FR} \alpha\left(\mathrm{IC}_{50}=2.1 \pm 0.4\right.$ and $0.6 \pm 0.3 \mathrm{nM}$, respectively $)$ and $\mathrm{FR} \beta(0.8 \pm 0.2$ and $0.3 \pm 0.1 \mathrm{nM}$, respectively) were determined. The autoradiography signal obtained with ${ }^{18} \mathrm{~F}$-6R-aza-5-MTHF was 11 -fold more intense for RT16 than for D4 tissue sections. Biodistribution data showed high uptake of ${ }^{18} \mathrm{~F}$ - $6 R$-aza5-MTHF in RT16 xenografts $(81 \pm 20 \% \mathrm{IA} / \mathrm{g}, 1 \mathrm{~h}$ p.i. $)$, but significantly lower accumulation in D4 xenografts $(7.3 \pm 2.1 \% \mathrm{IA} / \mathrm{g}, 1 \mathrm{~h}$ p.i. $)$ which was also visualized using PET. The uptake of ${ }^{18} \mathrm{~F}-6 S$-aza-5MTHF and ${ }^{18} \mathrm{~F}-\mathrm{AzaFol}$ was similar in RT16 $(53 \pm 10 \% \mathrm{IA} / \mathrm{g}$ and $45 \pm 2 \% \mathrm{IA} / \mathrm{g}$, respectively $)$ and D4 xenografts $(77 \pm 10 \% \mathrm{IA} / \mathrm{g}$ and $52 \pm 7 \% \mathrm{IA} / \mathrm{g}$, respectively).

Conclusion This study demonstrated FR $\alpha$ selectivity for ${ }^{18} \mathrm{~F}$ - $6 R$-aza-5-MTHF but not for ${ }^{18} \mathrm{~F}$ - $6 S$-aza-5MTHF and ${ }^{18} \mathrm{~F}$-AzaFol. This characteristic, together with its favorable tissue distribution, make ${ }^{18} \mathrm{~F}-6 R$-aza5-MTHF attractive for clinical translation to enable detection of FR $\alpha$-positive cancer while preventing undesired accumulation in FR $\beta$-expressing inflammatory cells. 
Keywords folate receptor (FR), 5-MTHF, PET, ${ }^{18} \mathrm{~F}, \mathrm{FR} \alpha$ selectivity 


\section{INTRODUCTION}

The folate receptor- $\alpha(\mathrm{FR} \alpha)$ is a cell membrane-associated protein which has been used for targeted therapies in oncology (1). Among FR $\alpha$-expressing malignancies are mainly gynecologic cancers, such as ovarian, endometrial and cervical tumors, but non-small cell lung cancer, triple-negative breast cancer and kidney cancer were also reported to be frequently positive for the FR $\alpha(2-6)$.

The use of folic acid-based radiotracers for nuclear imaging was proposed for diagnosis of FR-positive cancer and for the selection of patients who would profit from FR-targeted tumor therapies $(7-10) .{ }^{111}$ InDTPA-folate and ${ }^{99 \mathrm{~m}} \mathrm{Tc}-\mathrm{EC} 20$ suitable for single photon emission computed tomography were the first two folate radioconjugates tested in patients $(8,11,12)$. Folic acid-based radiotracers bind to both the FR $\alpha$ and the FR $\beta$, which have distinct tissue expression profiles $(13,14)$. The FR $\alpha$ is present in malignant tissue (15), whereas the FR $\beta$ is mainly expressed on activated macrophages involved in inflammatory diseases (16). As a result, folic acid-based radiotracers accumulate not only in tumors but also at sites of inflammation, which may result in false-positive findings due to co-existing inflammatory conditions in cancer patients.

6S/6R-5-methyltetrahydrofolates (MTHF) are reduced folate forms, in contrast to folic acid, which is the synthetic, oxidized version of folate vitamins. It was previously reported that the physiological $6 S-5$ MTHF, but not the $6 R-5-\mathrm{MTHF}$, binds with $\sim 50$-fold higher affinity to the FR $\alpha$ than to the FR $\beta(17,18)$. In a proof-of-concept study published by Low and co-workers, a dimethylated reduced version of ${ }^{99 \mathrm{~m}} \mathrm{Tc}-\mathrm{EC} 20$ was prepared to achieve FR $\alpha$ selectivity (19). Indeed, it was experimentally demonstrated that ${ }^{99 \mathrm{~m}} \mathrm{Tc}-$ DMTHF accumulated much more in tumors of mice than at sites of inflammation (19).

In view of a clinical application, folate radiotracers for positron emission tomography (PET) imaging would be clearly favored $(20,21) .{ }^{18} \mathrm{~F}$-based radiotracers profit from the favorable decay characteristics of

${ }^{18} \mathrm{~F}\left(\mathrm{~T}_{1 / 2}=110 \mathrm{~min}, \mathrm{E} \beta^{+}{ }_{\text {average }}=250 \mathrm{keV}\right)$ and the option of quantifying the accumulated activity using standard protocols that are also employed for interventions with 2-deoxy-2- ${ }^{18} \mathrm{~F}$-D-glucose (22).

Among a large number of developed ${ }^{18} \mathrm{~F}$-folate tracers (21) only two were employed in clinics. Verweij et al. reported on the use of ${ }^{18} \mathrm{~F}-\mathrm{PEG}$-folate for macrophage imaging in patients with rheumatoid arthritis (23), whereas ${ }^{18} \mathrm{~F}$-AzaFol has recently been tested in a clinical Phase I trial in ovarian and lung cancer 
patients in Switzerland (NCT0342993) (24,25). A tumor-selective ${ }^{18} \mathrm{~F}$-folate tracer for PET, that targets solely the FR $\alpha$ but not the FR $\beta$, would be essential to unambiguously identify patients that could profit from FR $\alpha$-targeted therapies.

We have previously developed radiotracers based on $6 S$ - and $6 R$-5-MTHF as a targeting agent (26), in which the ${ }^{18} \mathrm{~F}$-label was integrated in the folate backbone as it was the case for ${ }^{18} \mathrm{~F}$-AzaFol (Fig. 1) (26). These 5-MTHF-based ${ }^{18} \mathrm{~F}$-tracers accumulated to a higher extent in tumor xenografts of mice than ${ }^{18} \mathrm{~F}$ AzaFol, and the $6 R$-isomer showed even a favorable excretion profile. The goal of the present study was, therefore, to investigate ${ }^{18} \mathrm{~F}-6 R$-aza-5-MTHF and ${ }^{18} \mathrm{~F}-6 S$-aza-5-MTHF with regard to their binding affinity to the FR $\alpha$ and FR $\beta$, respectively, in order to assess the potential of using them for tumor-selective PET imaging.

\section{MATERIALS AND METHODS}

\section{Folate Derivatives}

The precursors (6R- or $6 S-N^{2}$-acetyl-3'-aza-2'-chloro-5-MTHF di-tert-butylester and $N^{2}$-acetyl-3'-aza2'-chlorofolic acid di-tert-butylester) for the radiofluorination and the non-radioactive 6S-5-MTHF (physiological form) and 6R-5-MTHF (non-physiological form) were provided by Merck \& Cie, Switzerland. Folic acid was obtained from Sigma-Aldrich, Switzerland. The non-radioactive fluoro-folates as well as the $6 R$-3'-aza-2'- ${ }^{18} \mathrm{~F}-5$-methyltetrahydrofolate $\left({ }^{18} \mathrm{~F}-6 R\right.$-aza-5-MTHF), $6 S$-3'-aza-2'- ${ }^{18} \mathrm{~F}-5$ methyltetrahydrofolate $\left({ }^{18} \mathrm{~F}-6 S\right.$-aza-5-MTHF) and 3 -aza-2'- ${ }^{18} \mathrm{~F}$-folic acid $\left({ }^{18} \mathrm{~F}\right.$-AzaFol $)$ were synthesized at ETH Zurich according to a previously reported method $(24,26)$. The molar activity of the radiotracers was in the range of 20-250 GBq/ $\mathrm{mol}$ with commonly higher values for ${ }^{18} \mathrm{~F}$-AzaFol than for the 5-MTHF-based radiotracers $(24,26) .{ }^{3} \mathrm{H}$-folic acid was obtained from Moravek Biochemicals, Inc. California, U.S.A..

\section{Cell Culture}

CHO cells transfected with the FR $\alpha$ (designated as RT16) or FR $\beta$ (designated as D4) were kindly provided by Prof. L. Matherly, Wayne State University, Detroit, U.S.A. (27). The cells were cultured in 
folate-free minimal essential medium-alpha. KB cells (FR-positive, human cervical carcinoma cell line, ACC-136) were obtained from the German Collection of Microorganisms and Cell Cultures (DSMZ, GmbH, Germany) and cultured in folate-deficient RPMI medium. PC-3 cells (FR-negative, human prostate cancer cell line, ACC-465) were also obtained from DSMZ but cultured in normal RPMI 1640 medium. Cell culture media were supplemented with $10 \%$ fetal calf serum, L-glutamine and antibiotics.

\section{Western Blot}

Expression of the FR $\alpha$ and FR $\beta$ in RT16 and D4 cells, respectively, was verified by Western blot analysis whereas FR $\alpha$-expressing KB and FR-negative PC-3 tumor cells were used as positive and negative controls, respectively. Cell protein extracts (30 $\mathrm{g}$ /well) were separated by SDS-PAGE and transferred to a polyvinylidene difluoride membrane. After blocking with $5 \%$ bovine serum albumin (BSA) solution, the membrane was incubated with a primary anti-FR $\alpha$ antibody (1:625, rabbit mAb, PA5-42004, Invitrogen) or anti-FR $\beta$ antibody (1:1000, rabbit mAb, GTX105822, GeneTex) overnight at $4{ }^{\circ} \mathrm{C}$. For signal detection, a secondary anti-rabbit IgG antibody functionalized with horseradish peroxidase was used together with chemiluminescent substrate. Detection of $\beta$-actin served as a loading control (anti- $\beta$-actin antibody; 1:2000, mouse mAb, 3700, Cell Signaling Technology and (HRP)-conjugated anti-mouse IgG, 1:5000, 7076S, Cell Signaling Technology). The expression of the FR $\alpha$ and FR $\beta$ on RT16 and D4 cells, respectively, was assessed by comparison of the signal with that of KB cells and shown on one representative Western blot.

\section{Cell Internalization of ${ }^{18}$ F-6R/6S-aza-5-MTHF and ${ }^{18}$ F-AzaFol}

Cell uptake of ${ }^{18} \mathrm{~F}-6 R$-aza-5-MTHF, ${ }^{18} \mathrm{~F}-6 S$-aza-5-MTHF and ${ }^{18} \mathrm{~F}$-AzaFol was determined as previously reported $(26,28)$. In brief, RT16 and D4 cells were seeded in poly-L-lysine coated 12-well plates to form confluent monolayers overnight. The cells were incubated with the ${ }^{18} \mathrm{~F}$-folate radiotracer $(\sim 200 \mathrm{kBq} ; 25 \mu \mathrm{L})$ with or without excess folic acid $(\sim 100 \mu \mathrm{M})$ for $3 \mathrm{~h}$ at $37^{\circ} \mathrm{C}$. The results were expressed as percentage of total added activity. The statistical significance was assessed using a two-way ANOVA with Tukey's multiple comparisons post-test using GraphPad Prism software (version 7.0). A $p$-value of $<0.05$ was considered as statistically significant. 


\section{FRo- and FRß-Binding Affinity ( $\mathrm{IC}_{50}$ Values)}

The binding affinities ( $\mathrm{IC}_{50}$ values) to the $\mathrm{FR} \alpha$ and the FR $\beta$ were determined in displacement experiments using non-radioactive fluoro-folates $\left({ }^{19} \mathrm{~F}-6 S\right.$-aza-5-MTHF, ${ }^{19} \mathrm{~F}-6 R$-aza-5-MTHF and ${ }^{19} \mathrm{~F}$ AzaFol) and ${ }^{3} \mathrm{H}$-folic acid as previously reported (24). The binding affinities of the corresponding nonfluorinated analogues (6R-5-MTHF, $6 S-5-\mathrm{MTHF}$ and folic acid) were determined for comparison. The folate derivatives of interest were applied in a concentration range of $5 \mathrm{pM}-50 \mu \mathrm{M}$ (Supplemental Table 1). The FR-bound fraction of ${ }^{3} \mathrm{H}$-folic acid was measured using a $\beta$-counter (Packard Bioscience Cobra II). The $\mathrm{IC}_{50}$ values were determined by nonlinear regression analysis of displacement curves obtained from at least three independent experiments, using GraphPad Prism software (version 7.0). For comparison, the relative

affinities of ${ }^{19} \mathrm{~F}-6 S$-aza-5-MTHF and ${ }^{19} \mathrm{~F}-6 R$-aza-5-MTHF were presented as percentage of the binding affinity determined for ${ }^{19} \mathrm{~F}$-AzaFol (set as $100 \%$, respectively). The receptor binding affinities of $6 R-5$ MTHF and 6S-5-MTHF were expressed relative to the determined binding affinity of folic acid (set as 100\%, respectively).

\section{Autoradiography Studies}

Autoradiography studies were performed using tissue sections of RT16, D4, KB and PC-3 xenografts as previously reported (29). The sections were incubated in Tris- $\mathrm{HCl}$ buffer containing $0.25 \% \mathrm{BSA}$. After removal of the buffer, the sections were incubated with the ${ }^{18} \mathrm{~F}$-folate radiotracers $(150 \mathrm{kBq} / 100 \mu \mathrm{L})$ in Trisbuffer containing $1 \%$ BSA with or without addition of excess folic acid $(100 \mu \mathrm{M})$ for $1 \mathrm{~h}$ at room temperature. Autoradiographic images were obtained using a storage phosphor system (Cyclone Plus, Perkin Elmer) and quantified using OptiQuant software (version 5.0). The signals obtained from RT16, D4 and PC-3 xenograft sections were normalized to the signal obtained from KB xenograft section (set as $100 \%$ ). The resulting values of ${ }^{18} \mathrm{~F}-6 R$-aza-5-MTHF and ${ }^{18} \mathrm{~F}-6 S$-aza-5-MTHF were expressed relative to the signal of ${ }^{18} \mathrm{~F}$-AzaFol, which was set as $100 \%$. Representative images were prepared using ImageJ (version $1.52 \mathrm{~d})$. 


\section{Immunohistochemistry}

After deparaffinization, rehydration and antigen retrieval of the xenograft sections (RT16, D4 and KB), the slides were treated with 3.5\% hydrogen peroxide, followed by endogenous biotin blockade using avidin solution (Avidin/Biotin Blocking kit SP-2001, Vector Laboratories, U.S.A.) in a mixture of 3\% BSA and normal 5\% goat serum. The sections were incubated with an anti-FR $\alpha$ antibody (PA5-42004, Invitrogen) and an anti-FR $\beta$ antibody (GTX105822, GeneTex), diluted 1:800 and 1:400 in biotin solution mixed with $3 \%$ BSA, respectively, at $4{ }^{\circ} \mathrm{C}$ overnight. Afterwards, the sections were incubated with the secondary antibody (goat anti-rabbit IgG, BA-1000, Vector Laboratories, U.S.A.) diluted 1:1000 and 1:500 in PBS containing 3\% BSA. Signal visualization was performed using reagents of commercial kits $\left(\right.$ Vectostain ${ }^{\mathrm{TM}}$ Elite ABC-HRP kit, peroxidase PK-6100 and DAB substrate kit peroxidase (HRP), SK-4100, Vector Laboratories, U.S.A.), followed by counterstaining using hematoxylin. After tissue dehydration, the sections were fixed with xylene and images were taken using a light microscope (Axio Lab.A1, Zeiss).

\section{In Vivo Studies}

All applicable international, national and institutional guidelines for the care and use of laboratory animals were followed. The studies were carried out according to the guidelines of the Swiss Regulations for Animal Welfare after ethical approval by the Cantonal Committee of Animal Experimentation and permission by the responsible authorities. Female, severe combined immunodeficient CB17 mice were purchased from Charles River Laboratories (Sulzfeld, Germany). All animals were fed with a folatedeficient rodent diet (ssniff Spezialdiäten GmbH, Germany). The mice were inoculated with RT16 cells (6 $\times 10^{6}$ cells in $100 \mu \mathrm{L}$ PBS $)$ on the right shoulder and D4 cells $\left(6 \times 10^{6}\right.$ cells in $100 \mu \mathrm{L}$ PBS $)$ on the left shoulder. Biodistribution and PET/CT imaging studies were performed 8-10 days later.

\section{Biodistribution Studies}

Mice were injected into the lateral tail vein with the respective ${ }^{18} \mathrm{~F}$-folate radiotracer $(\sim 5 \mathrm{MBq}, 100 \mu \mathrm{L}$, $\sim 0.2 \mathrm{nmol}$ ) and sacrificed at $1 \mathrm{~h}$ and $3 \mathrm{~h} \mathrm{p}$.i. Selected tissues and organs were collected, weighed, and the activity was measured using a $\gamma$-counter (Perkin Elmer, Wallac Wizard 1480). The results of $n=3-4$ mice 
per time point were listed as a percentage of the injected activity per gram of tissue mass $(\% \mathrm{IA} / \mathrm{g})$, using counts of a standard solution (5\% IA) measured at the same time. The data sets were analyzed for significance using a one-way ANOVA with Tukey's multiple comparison post-test using GraphPad Prism software (version 7.0). A $p$-value of $<0.05$ was considered statistically significant.

\section{PET/CT Imaging Studies}

PET/CT scans were performed using a small-animal PET/CT scanner (G8, Perkin Elmer, U.S.A. (30)) as previously reported (26). After emptying the urinary bladder of the mice, they were anesthetized with a mixture of isoflurane (1.5-2.0\%) and oxygen for PET/CT acquisitions. Static whole-body PET scans of 10 min duration were performed at $1 \mathrm{~h}$ and $3 \mathrm{~h}$ after intravenous injection of ${ }^{18} \mathrm{~F}$-folate radiotracers $(5 \mathrm{MBq}$, $\sim 0.2 \mathrm{nmol}, 100 \mu \mathrm{L}$ ), followed by a CT scan of $1.5 \mathrm{~min}$. The acquisition of the data and their reconstruction was performed using the G8 PET/CT scanner software (version 2.0.0.10). The images show one representative example for each radiotracer, prepared using VivoQuant post-processing software (version 3.5, inviCRO Imaging Services and Software, U.S.A.).

\section{RESULTS}

\section{Uptake of ${ }^{18}$ F-Radiotracers in FR $\alpha$-positive RT16 and FRß-positive D4 Cells}

Western blot analysis unambiguously confirmed FR $\alpha$ expression on RT16 cells and FR $\beta$ expression on D4 cells by detection of the bands at $38 \mathrm{kDa}$ and $29 \mathrm{kDa}$, respectively (Fig. 2A). The quantified signal for the FR $\alpha$ on RT16 cells and the FR $\beta$ on D4 cells was in the range of $20-45 \%$ of the FR $\alpha$ signal of KB cells. Only a weak signal of 6-7\% was obtained for the FR $\alpha$ on D4 cells and the FR $\beta$ signal on RT16 cells, respectively. This was in the same range as the signal for PC-3 cells (5-6\%) which are FR-negative (Supplemental Fig. 1) (31).

The uptake of ${ }^{18} \mathrm{~F}-6 R$-aza-5-MTHF (62 $\pm 10 \%$ of total added activity) and ${ }^{18} \mathrm{~F}$ - $6 S$-aza-5-MTHF (64 \pm $15 \%)$ into RT16 cells was in the same range as for ${ }^{18} \mathrm{~F}$-AzaFol $(52 \pm 4 \%)$ after a $3 \mathrm{~h}$-incubation period $(p>0.05)$. The internalized fractions of all three radiotracers were in the range of $11-13 \%$ of total added activity ( $p>0.05)$. FR $\alpha$-specific uptake was confirmed by complete blockade of radiotracer uptake in cell 
samples pre-incubated with excess folic acid (Fig. 2B). Experiments performed with D4 cells showed significantly lower uptake of ${ }^{18} \mathrm{~F}-6 R$-aza-5-MTHF $(5 \pm 2 \% ; p<0.05)$ than of ${ }^{18} \mathrm{~F}$-6S-aza-5-MTHF $(70 \pm 7 \%)$ and ${ }^{18} \mathrm{~F}$-AzaFol $(61 \pm 14 \%)$ which were both in the same range $(p>0.05)$. Co-incubation of D4 cells with excess folic acid reduced the uptake of all radiotracers to background levels $(<0.1 \%)$ (Fig. 2B).

\section{FRo- and FRß-Binding Affinity ( $\mathrm{IC}_{50}$ Values)}

The binding affinity of ${ }^{19} \mathrm{~F}-6 R$-aza-5-MTHF to the FR $\alpha$ was $\sim 40$-fold higher ( $\mathrm{IC}_{50}$ values: $1.8 \pm 0.1$ $\mathrm{nM})$ than to the FR $\beta(77 \pm 27 \mathrm{nM})$. In contrast, the binding affinity of ${ }^{19} \mathrm{~F}-6 S$-aza-5-MTHF was similar to both FR isoforms $\left(2.1 \pm 0.4 \mathrm{nM}\right.$ and $0.8 \pm 0.2 \mathrm{nM}$, respectively) and the same held true also for ${ }^{19} \mathrm{~F}$-AzaFol $(0.6 \pm 0.3 \mathrm{nM}$ and $0.3 \pm 0.1 \mathrm{nM}$, respectively). These findings corresponded well with the determined values of the respective non-fluorinated analogues demonstrating a $\sim 70$-fold increased binding of $6 S-5$-MTHF to the FR $\alpha$ than to the FR $\beta$, but equal binding affinities to both FR-isoforms for $6 R$-5-MTHF and folic acid (Table 1, Supplemental Fig. 2).

Determination of the FR $\alpha$-binding affinity of ${ }^{19} \mathrm{~F}-6 R$-aza-5-MTHF and ${ }^{19} \mathrm{~F}$-6S-aza-5-MTHF relative to

${ }^{19} \mathrm{~F}-\mathrm{AzaFol}$ (set as 100\%) revealed a lower value for the reduced folates (29-34\%) which was in line with the results obtained for non-fluorinated $6 S-5-\mathrm{MTHF}$ and $6 R-5-\mathrm{MTHF}$ relative to folic acid (28-44\%). The relative binding affinity to the FR $\beta$ was 300 -fold lower for ${ }^{19} \mathrm{~F}-6 R$-aza-5-MTHF as compared to ${ }^{19} \mathrm{~F}$-AzaFol, whereas the FR $\beta$-binding affinity of ${ }^{19} \mathrm{~F}-6 \mathrm{~S}$-aza-5-MTHF was only slightly reduced, which corresponded well with the binding affinities to the FR $\beta$ of the non-fluorinated folates relative to folic acid (Table 1).

\section{Autoradiography Studies Using ${ }^{18}$ F-Folate Tracers}

In vitro autoradiography studies revealed a similar signal intensity on RT16 xenograft sections for ${ }^{18} \mathrm{~F}$ $6 R$-aza-5-MTHF $(74 \pm 28 \%)$ and ${ }^{18} \mathrm{~F}-6 S$-aza-5-MTHF $(89 \pm 33 \%)$ which was comparable to the signal of ${ }^{18} \mathrm{~F}$-AzaFol (set as 100\%) (Fig. 3). A similar binding pattern was obtained with FR $\alpha$-positive KB xenograft sections (Supplemental Fig. 3). The images obtained with D4 xenograft sections demonstrated, however, an over 10 -fold lower signal for ${ }^{18} \mathrm{~F}-6 R$-aza-5-MTHF $(7 \pm 4 \% ; p<0.05)$ as compared to the signal intensity of 
${ }^{18} \mathrm{~F}$-6S-aza-5-MTHF $\left(81 \pm 36 \%\right.$ ) relative to ${ }^{18} \mathrm{~F}$-AzaFol (set as $100 \%$ ). Co-incubation of ${ }^{18} \mathrm{~F}$-folates with excess folic acid to block the FR-specific binding resulted in only background signals, comparable with those obtained for FR-negative PC-3 tissue (Supplemental Fig. 3).

The expression of the FR $\alpha$ on RT16 (and KB as a positive control) and the FR $\beta$ on D4 xenograft sections, was verified by a positive immunohistochemical staining using an anti-FR $\alpha$ antibody and anti-FR $\beta$ antibody. The non-specific binding was determined in the absence of the primary antibody (Supplemental Fig. 4).

\section{Biodistribution of ${ }^{18} \mathrm{~F}$-Folate Tracers}

Biodistribution studies were performed in RT16/D4 xenograft-bearing mice. At $1 \mathrm{~h}$ and $3 \mathrm{~h}$ after injection of ${ }^{18} \mathrm{~F}-6 R$-aza-5-MTHF, the uptake of into FR $\alpha$-positive RT16 xenografts ranged from $81-94 \%$ $\mathrm{IA} / \mathrm{g}$ and was significantly higher than the uptake into FR $\beta$-positive D4 xenografts $(7.3-7.6 \% \mathrm{IA} / \mathrm{g} ; p<0.05)$ (Fig. 4). The accumulation of ${ }^{18} \mathrm{~F}-6 S$-aza-5-MTHF was in the same range for both xenograft types (RT16: 53-122\% IA/g; D4: 77-149\% IA/g) which was also the case for ${ }^{18} \mathrm{~F}-\mathrm{AzaFol}$ (RT16: 26-45\% IA/g; D4: 28 $52 \%$ IA/g) (Fig. 4). The higher uptake of 5-MTHF-based ${ }^{18}$ F-folate tracers in FR $\alpha$-positive RT16 xenografts compared to the uptake of ${ }^{18} \mathrm{~F}$-AzaFol was in line with previous data obtained with $\mathrm{KB}$ tumor-bearing nude mice (26).

The herein presented data obtained with severe combined immunodeficient CB17 mice showed a 3fold-lower renal retention of ${ }^{18} \mathrm{~F}-6 R$-aza-5-MTHF (11-25\% IA/g) than for ${ }^{18} \mathrm{~F}-6 S$-aza-5-MTHF $(31-41 \%$ $\mathrm{IA} / \mathrm{g}$ ) and ${ }^{18} \mathrm{~F}-\mathrm{AzaFol}(35-58 \% \mathrm{IA} / \mathrm{g})$ as previously observed in nude mice (Supplemental Tables 2-4) (26).

\section{PET/CT Imaging Studies Using ${ }^{18}$ F-Folate Tracers}

Mice bearing RT16 and D4 xenografts on the right and left shoulders, respectively, were imaged at 1 $\mathrm{h}$ and $3 \mathrm{~h}$ after injection of the ${ }^{18} \mathrm{~F}$-folate radiotracers using preclinical PET/CT (Fig. 5). In agreement with the biodistribution data, a selective accumulation of ${ }^{18} \mathrm{~F}-6 R$-aza-5-MTHF in the RT16 xenograft was readily visualized on PET/CT images. This was in a clear contrast to the images obtained after injection of ${ }^{18} \mathrm{~F}-6 S$ aza-5-MTHF and ${ }^{18}$ F-AzaFol, which accumulated equally in RT16 and D4 xenografts. The PET images further confirmed the previously published data that showed much less retention of ${ }^{18} \mathrm{~F}-6 R$-aza-5-MTHF in 
the kidneys as compared to ${ }^{18} \mathrm{~F}-6 S$-aza-5-MTHF and ${ }^{18} \mathrm{~F}$-AzaFol (26). The RT16 xenograft-to-kidney ratios were, thus, considerably higher for the $6 R$-isomer than for the $6 S$-isomer while the opposite held true for the xenograft-to-liver ratios.

\section{DISCUSSION}

FR-targeted cancer therapies including folic acid-drug conjugates (e.g. vintafolide $(32,33)$ ), FR $\alpha$ targeted antibodies (e.g. farletuzumab (34)) or FR $\alpha$ antibody-drug conjugates (e.g. mirvetuximab soravtansine (35)) hold promise for the treatment of patients with FR $\alpha$-positive tumors $(1,8)$. The response to these therapies will, however, critically depend on the patient inclusion criteria, which should only consider cases with the majority of lesions being FR $\alpha$-positive (36). While ${ }^{18} \mathrm{~F}$-AzaFol visualizes FRpositive tissue on PET images (25), false-positive results may occur due to concomitant accumulation of the radiotracer in FR $\beta$-expressing macrophages involved at sites of inflammation. Having a means in hands to provide a full picture of FR $\alpha$-positive lesions in an individual patient would, thus, present an essential step for the success of any FR $\alpha$-targeted cancer therapy concept $(1,8)$.

In this study, we have demonstrated that $6 R$-aza-5-MTHF displayed significantly higher affinity to the FR $\alpha$ than to the FR $\beta$ indicating the anticipated FR $\alpha$ selectivity. These findings were in agreement with those obtained with the corresponding non-fluorinated versions of 5-MTHF that confirmed the original observation of Wang et al. who reported on the $\sim 50$-fold higher affinity of $6 S-5$-MTHF to the FR $\alpha$ than to the FR $\beta(17,18)$. Folic acid and the non-physiological $6 R-5-\mathrm{MTHF}$ as well as their fluorinated analogues showed, however, equal binding to both FR-isoforms.

The fact that only the $6 R$-isomer of the novel aza-5-MTHF-based ${ }^{18} \mathrm{~F}$-folate tracers bound with higher affinity to the FR $\alpha$ than to the FR $\beta$, but not the $6 S$-isomer, is an essential finding. It indicates the need for diastereomerically pure folate radiotracers other than previously proposed by the development of a racemic mixture of ${ }^{99 \mathrm{~m}} \mathrm{Tc}-\mathrm{DMTHF}$, a reduced form of ${ }^{99 \mathrm{~m}} \mathrm{Tc}-\mathrm{EC} 20$ (19).

The in vivo evaluation of tumor-specific folate radiotracers in the presence of inflammation is challenging in mice, since the number of activated macrophages is commonly low and, hence, the expected 
signal from inflammatory sites is smaller than the signal from the tumor tissue. This situation may complicate the interpretation of the results with regard to FR $\alpha$ selectivity. In order to unambiguously determine whether the ${ }^{18} \mathrm{~F}$-folate radiotracers accumulated specifically in FR $\alpha$-expressing tissue, we have established a mouse model using RT16 and D4 cells to grow xenografts of comparable volumes. Using these mice enabled the determination of FR $\alpha$-selective uptake of ${ }^{18} \mathrm{~F}-6 R$-aza-5-MTHF in RT16 xenografts, while the accumulation in D4 xenografts was significantly lower. In contrast, ${ }^{18} \mathrm{~F}-6 S$-aza-5-MTHF as well as ${ }^{18} \mathrm{~F}$-AzaFol showed comparable accumulation in both xenografts.

It is important to recognize that in addition to the FR $\alpha$-selective accumulation of ${ }^{18} \mathrm{~F}-6 R$-aza-5-MTHF, this radiotracer also showed the most favorable clearance from background tissues, including the kidneys as previously demonstrated by Boss et al., who used KB tumor-bearing nude mice (26). The somewhat lower FR $\alpha$-binding affinity of the 5-MTHF-based ${ }^{18} \mathrm{~F}$-radiotracers as compared to the affinity of ${ }^{18} \mathrm{~F}$-AzaFol is in line with the common knowledge that reduced folates display lower FR binding affinity than folic acid $(15,17,18)$. While the high FR-binding affinity of folic acid was postulated as a particular advantage of FRtargeting agents, we believe that 5-MTHF-based ${ }^{18} \mathrm{~F}$-radiotracers may be favorably used for this purpose as they may be more efficiently released from the FR upon internalization (37). This could explain the higher uptake of ${ }^{18} \mathrm{~F}-6 R$-aza-5-MTHF and ${ }^{18} \mathrm{~F}-6 S$-aza-5-MTHF in RT16 and KB xenografts as compared to ${ }^{18} \mathrm{~F}$ AzaFol (26).

\section{CONCLUSION}

In this study, we have identified ${ }^{18} \mathrm{~F}-6 R$-aza-5-MTHF as a novel PET agent, which accumulated in FR $\alpha$ positive RT16 xenografts, but not in FR $\beta$-positive D4 xenografts grown in the same mouse. The favorable

tissue distribution profile of ${ }^{18} \mathrm{~F}-6 R$-aza-5-MTHF, together with the herein determined FR $\alpha$ selectivity, means a breakthrough in the field. ${ }^{18} \mathrm{~F}-6 R$-aza-5-MTHF could serve for the unambiguous identification of patients that can profit from FR $\alpha$-targeted therapies and, thus, deserves highest attention in view of a clinical translation. 


\section{DISCLOSURE}

A patent application ${ }^{18}$ F-based folate radiotracers have been filed by Merck \& Cie whereby Roger Schibli, Simon M. Ametamey, Silvan D. Boss and Cristina Müller are co-inventors. The project was financially supported by Merck \& Cie (Schaffhausen, Switzerland) and by the Swiss National Science Foundation (grants 310030_156803 and 310030_188968). Patrycja Guzik was financially supported by a Swiss Government Excellence Scholarship. No other potential conflicts of interest relevant to this article exist.

\section{ACKNOWLEDGMENTS}

The authors thank Anna Becker, Raffaella Schmid and Fan Sozzi-Guo for technical assistance of the experiments. They would like to thank Annette Krämer for producing the ${ }^{18} \mathrm{~F}$-based radiotracers at ETH.

\section{KEY POINTS:}

QUESTION: Are 5-MTHF-based PET agents specific for the tumor-associated FR $\alpha$ ?

PERTINENT FINDINGS: The data of this preclinical study confirm FR $\alpha$-specific binding of ${ }^{18} \mathrm{~F}-6 R$-aza-5MTHF which will, as such, serve as a tumor-specific folate-based PET agent.

IMPLICATIONS FOR PATIENT CARE: The unambiguous identification of FR $\alpha$-expressing tumor types, without the risk of false-positive results due to FR $\beta$-expressing immune cells at sites of inflammation, will be essential in view of the PET agent's application for the selection of patients that could profit from FR $\alpha$ targeted therapies.

\section{ETHICAL APPROVAL}

This study was performed in agreement with the national law and PSI-internal guidelines of radiation safety protection. In vivo experiments were approved by the local veterinarian department and ethics committee and conducted in accordance with the Swiss law of animal protection. 


\section{AUTHOR INFORMATION}

\section{Corresponding Author}

PD Dr. Cristina Müller, Center for Radiopharmaceutical Sciences ETH-PSI-USZ, Paul Scherrer Institute, 5232 Villigen-PSI, Switzerland. E-mail: cristina.mueller@psi.ch. Phone: +41 5631044 54. Fax: +41 56 3102849. 


\section{REFERENCES}

1. Scaranti M, Cojocaru E, Banerjee S, Banerji U. Exploiting the folate receptor alpha in oncology. Nat Rev Clin Oncol. 2020;17:349-359.

2. Parker N, Turk MJ, Westrick E, Lewis JD, Low PS, Leamon CP. Folate receptor expression in carcinomas and normal tissues determined by a quantitative radioligand binding assay. Anal Biochem. 2005;338:284-293.

3. Low PS, Kularatne SA. Folate-targeted therapeutic and imaging agents for cancer. Curr Opin Chem Biol. 2009;13:256-262.

4. Assaraf YG, Leamon CP, Reddy JA. The folate receptor as a rational therapeutic target for personalized cancer treatment. Drug Resist Updat. 2014;17:89-95.

5. Zhang Z, Wang J, Tacha DE, et al. Folate receptor alpha associated with triple-negative breast cancer and poor prognosis. Arch Pathol Lab Med. 2014;138:890-895.

6. Norton N, Youssef B, Hillman DW, et al. Folate receptor alpha expression associates with improved disease-free survival in triple negative breast cancer patients. NPJ Breast Cancer. 2020;6:4.

7. Pribble P, Edelman MJ. EC145: a novel targeted agent for adenocarcinoma of the lung. Expert Opin Investig Drugs. 2012;21:755-761.

8. Teng L, Xie J, Teng L, Lee RJ. Clinical translation of folate receptor-targeted therapeutics. Expert Opin Drug Deliv. 2012;9:901-908.

9. $\mathrm{Xu}$ L, Bai Q, Zhang X, Yang H. Folate-mediated chemotherapy and diagnostics: An updated review and outlook. J Control Release. 2017;252:73-82.

10. Farran B, Pavitra E, Kasa P, Peela S, Rama Raju GS, Nagaraju GP. Folate-targeted immunotherapies: Passive and active strategies for cancer. Cytokine Growth Factor Rev. 2019;45:45-52.

11. Siegel BA, Dehdashti F, Mutch DG, et al. Evaluation of ${ }^{111}$ In-DTPA-folate as a receptor-targeted diagnostic agent for ovarian cancer: initial clinical results. $J$ Nucl Med. 2003;44:700-707.

12. Fisher RE, Siegel BA, Edell SL, et al. Exploratory study of ${ }^{99 \mathrm{~m}} \mathrm{Tc}-\mathrm{EC} 20$ imaging for identifying patients with folate receptor-positive solid tumors. $J$ Nucl Med. 2008;49:899-906. 
13. Low PS, Henne WA, Doorneweerd DD. Discovery and development of folic-acid-based receptor targeting for imaging and therapy of cancer and inflammatory diseases. Acc Chem Res. 2008;41:120129.

14. Müller C. Folate based radiopharmaceuticals for imaging and therapy of cancer and inflammation. Curr Pharm Des. 2012;18:1058-1083.

15. Antony AC. Folate receptors. Annu Rev Nutr. 1996;16:501-521.

16. Yi YS. Folate receptor-targeted diagnostics and therapeutics for inflammatory diseases. Immune Netw. 2016;16:337-343.

17. Wang X, Shen F, Freisheim JH, Gentry LE, Ratnam M. Differential stereospecificities and affinities of folate receptor isoforms for folate compounds and antifolates. Biochem Pharmacol. 1992;44:18981901.

18. Maziarz KM, Monaco HL, Shen F, Ratnam M. Complete mapping of divergent amino acids responsible for differential ligand binding of folate receptors a and b. J Biol Chem. 1999;274:1108611091.

19. Vaitilingam B, Chelvam V, Kularatne SA, Poh S, Ayala-Lopez W, Low PS. A folate receptor-alphaspecific ligand that targets cancer tissue and not sites of inflammation. J Nucl Med. 2012;53:11271134.

20. Müller C. Folate-based radiotracers for PET imaging - update and perspectives. Molecules. 2013;18:5005-5031.

21. Boss SD, Ametamey SM. Development of folate receptor-targeted PET radiopharmaceuticals for tumor imaging-a bench-to-bedside journey. Cancers (Basel). 2020;12:1508.

22. Almuhaideb A, Papathanasiou N, Bomanji J. ${ }^{18}$ F-FDG PET/CT imaging in oncology. Ann Saudi Med. 2011;31:3-13.

23. Verweij NJF, Yaqub M, Bruijnen STG, et al. First in man study of $\left[{ }^{18}\right.$ F $]$ fluoro-PEG-folate PET: a novel macrophage imaging technique to visualize rheumatoid arthritis. Sci Rep. 2020;10:1047. 
24. Betzel T, Müller C, Groehn V, et al. Radiosynthesis and preclinical evaluation of 3'-Aza-2'$\left[{ }^{18} \mathrm{~F}\right]$ fluorofolic acid: a novel PET radiotracer for folate receptor targeting. Bioconjug Chem. $2013 ; 24: 205-214$.

25. Gnesin S, Müller J, Burger IA, et al. Radiation dosimetry of ${ }^{18} \mathrm{~F}$-AzaFol: A first in-human use of a folate receptor PET tracer. EJNMMI Res. 2020;10:32.

26. Boss SD, Müller C, Siwowska K, et al. Diastereomerically pure 6R- and 6S-3'-Aza-2'-1 ${ }^{18}$ F-fluoro-5methyltetrahydrofolates show unprecedentedly high uptake in folate receptor-positive KB tumors. $J$ Nucl Med. 2019;60:135-141.

27. Deng Y, Wang Y, Cherian C, et al. Synthesis and discovery of high affinity folate receptor-specific glycinamide ribonucleotide formyltransferase inhibitors with antitumor activity. $J$ Med Chem. 2008;51:5052-5063.

28. Müller C, Mindt TL, de Jong M, Schibli R. Evaluation of a novel radiofolate in tumour-bearing mice: promising prospects for folate-based radionuclide therapy. Eur J Nucl Med Mol Imaging. 2009;36:938-946.

29. Müller C, Forrer F, Schibli R, Krenning EP, de Jong M. SPECT study of folate receptor-positive malignant and normal tissues in mice using a novel ${ }^{99 \mathrm{~m}}$ Tc-radiofolate. $J$ Nucl Med. 2008;49:310-317.

30. Gu Z, Taschereau R, Vu NT, et al. Performance evaluation of G8, a high-sensitivity benchtop preclinical PET/CT tomograph. J Nucl Med. 2019;60:142-149.

31. Siwowska K, Schmid RM, Cohrs S, Schibli R, Müller C. Folate receptor-positive gynecological cancer cells: in vitro and in vivo characterization. Pharmaceuticals (Basel). 2017;10.

32. Lorusso PM, Edelman MJ, Bever SL, et al. Phase I study of folate conjugate EC145 (vintafolide) in patients with refractory solid tumors. J Clin Oncol. 2012;30:4011-4016.

33. Luyckx M, Votino R, Squifflet JL, Baurain JF. Profile of vintafolide (EC145) and its use in the treatment of platinum-resistant ovarian cancer. Int J Womens Health. 2014;6:351-358.

34. Sato S, Itamochi H. Profile of farletuzumab and its potential in the treatment of solid tumors. Onco Targets Ther. 2016;9:1181-1188. 
35. Moore KN, Martin LP, O'Malley DM, et al. A review of mirvetuximab soravtansine in the treatment of platinum-resistant ovarian cancer. Future Oncol. 2018;14:123-136.

36. Morris RT, Joyrich RN, Naumann RW, et al. Phase II study of treatment of advanced ovarian cancer with folate-receptor-targeted therapeutic (vintafolide) and companion SPECT-based imaging agent ( ${ }^{99 m}$ Tc-etarfolatide). Ann Oncol. 2014;25:852-858.

37. Kamen BA, Smith AK. A review of folate receptor alpha cycling and 5-methyltetrahydrofolate accumulation with an emphasis on cell models in vitro. Adv Drug Deliv Rev. 2004;56:1085-1097. 


\section{Figures}
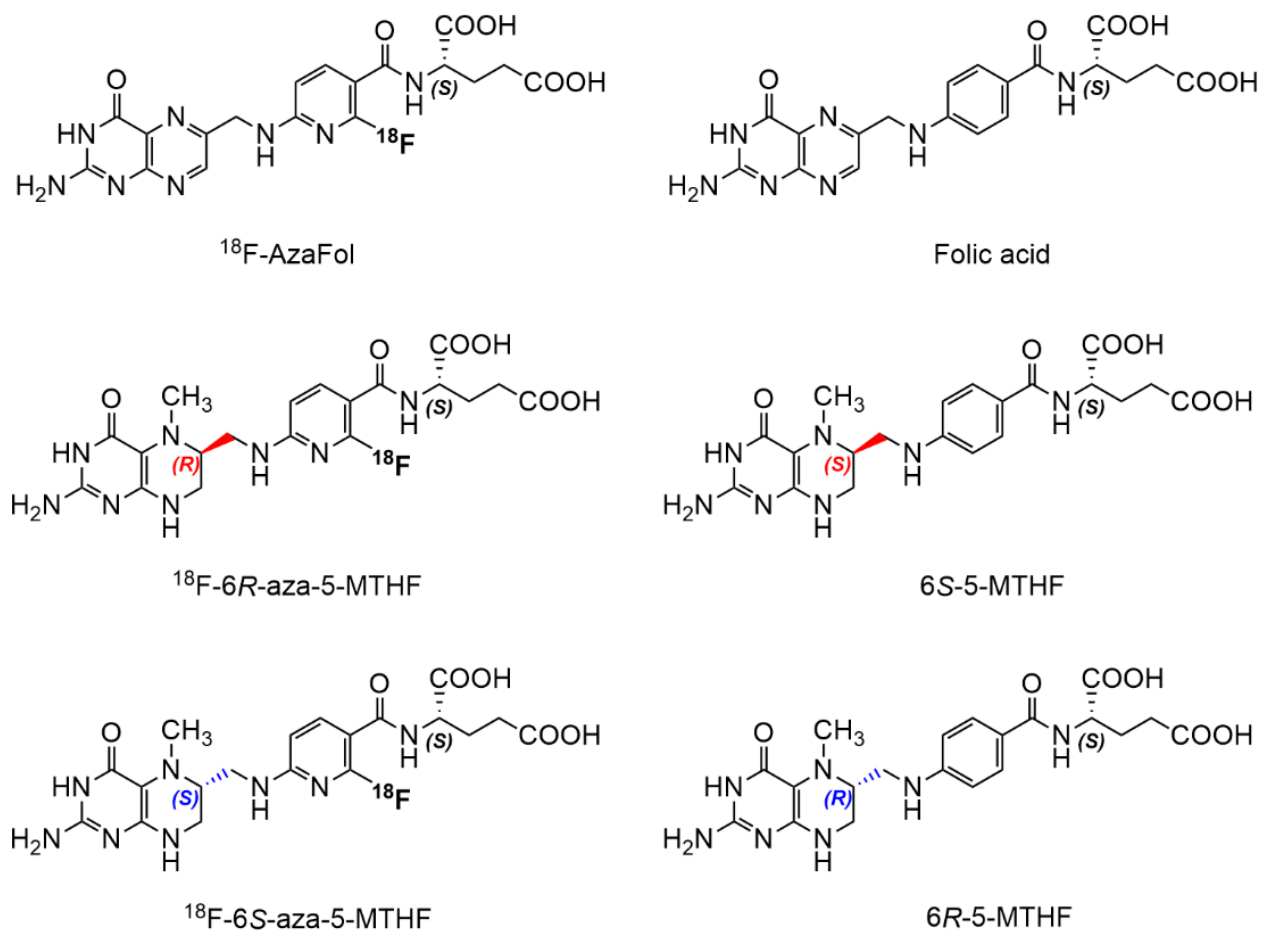

FIGURE 1. Chemical structures of ${ }^{18} \mathrm{~F}$-AzaFol, ${ }^{18} \mathrm{~F}-6 R$-aza-5-MTHF and ${ }^{18} \mathrm{~F}-6 S$-aza-5-MTHF as well as folic acid, $6 S-5-\mathrm{MTHF}$ and $6 R-5-\mathrm{MTHF}$ (26). Stereochemical nomenclature of the corresponding isomers of non-fluorinated and fluorinated 5-MTHFs are inversed due to the change in the substituents' priority at the stereogenic center. 
A

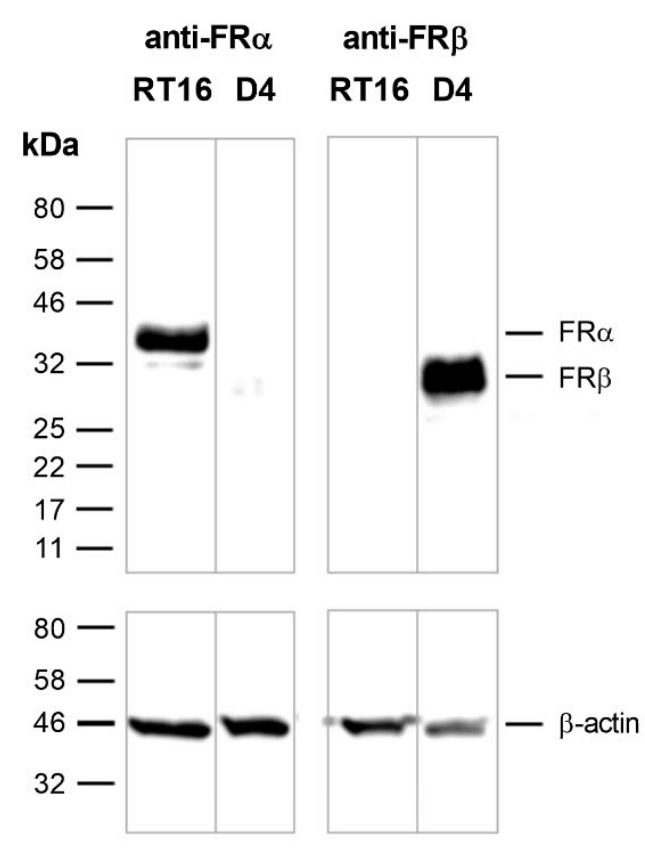

B
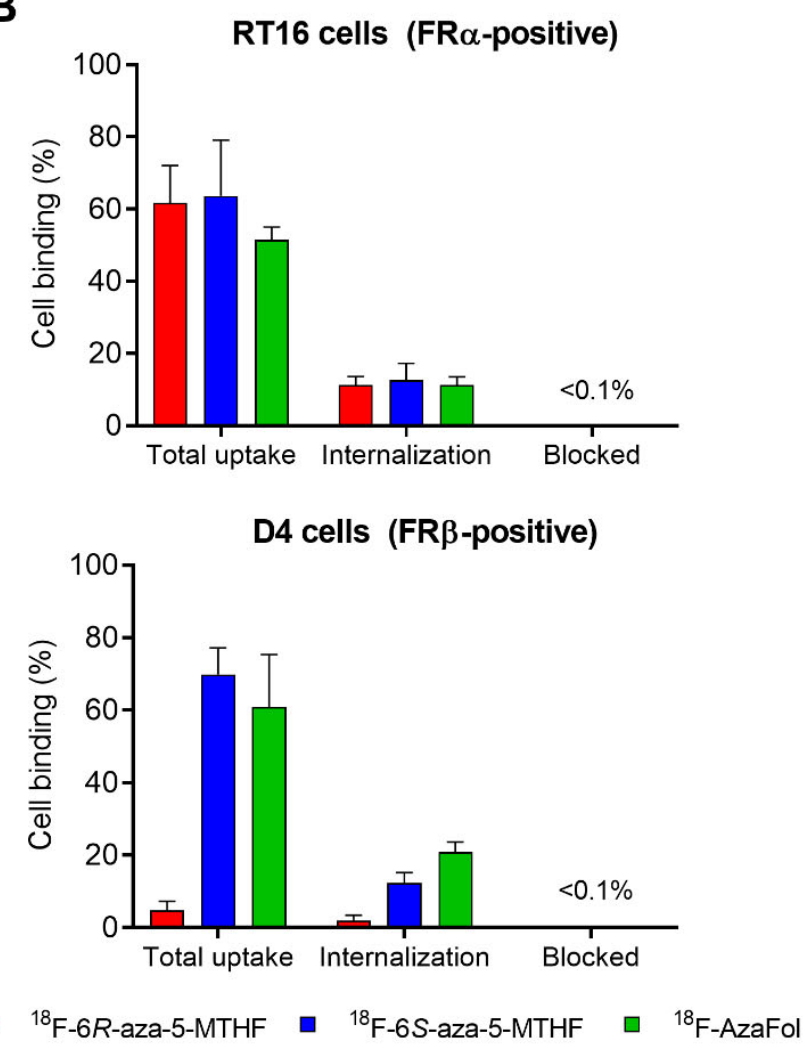

FIGURE 2. (A) Western blot analysis of FR $\alpha$ expression in RT16 cell lysates and FR $\beta$ expression in D4 cell lysates (top panel). Beta-actin-staining as a loading control (bottom panel). (B) Cell uptake and internalization of ${ }^{18} \mathrm{~F}-6 R$-aza-5-MTHF, ${ }^{18} \mathrm{~F}-6 \mathrm{~S}$-aza-5-MTHF and ${ }^{18} \mathrm{~F}$-AzaFol in RT16 and D4 cells after $3 \mathrm{~h}$ incubation at $37^{\circ} \mathrm{C}$. Unspecific binding of radiotracers (blocked) was determined by co-incubation of cells with folic acid $(100 \mu \mathrm{M})$. The results are presented as average \pm standard deviation $(\mathrm{SD})(\mathrm{n}=3)$. 

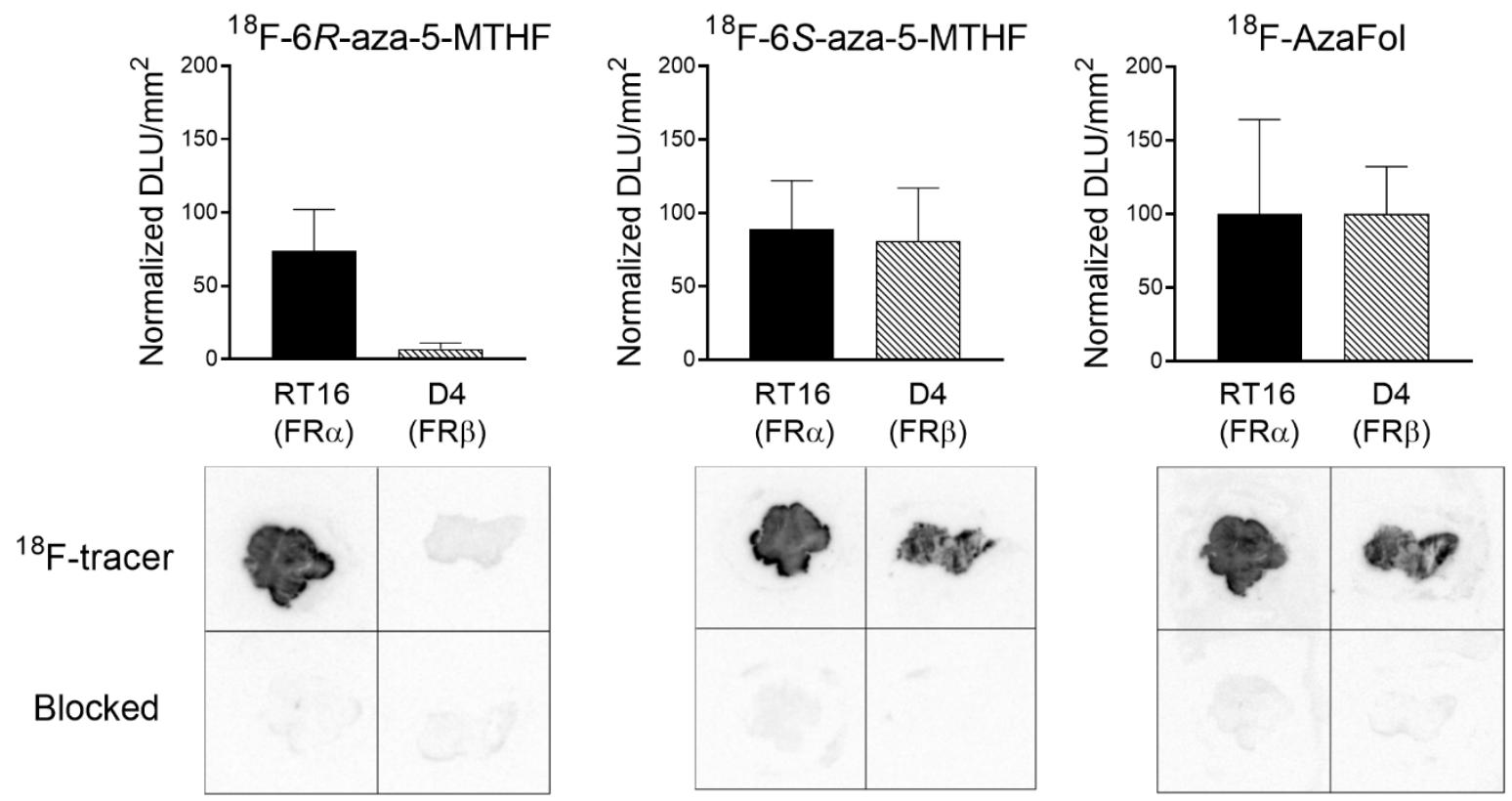

FIGURE 3. Signal intensities of ${ }^{18} \mathrm{~F}-6 R$-aza-5-MTHF, ${ }^{18} \mathrm{~F}-6 \mathrm{~S}$-aza-5-MTHF and ${ }^{18} \mathrm{~F}$-AzaFol (set as $100 \%$ ) quantified based on RT16 (left) or D4 (right) autoradiography images. The lower panel demonstrates FRblockade performed in excess folic acid. 


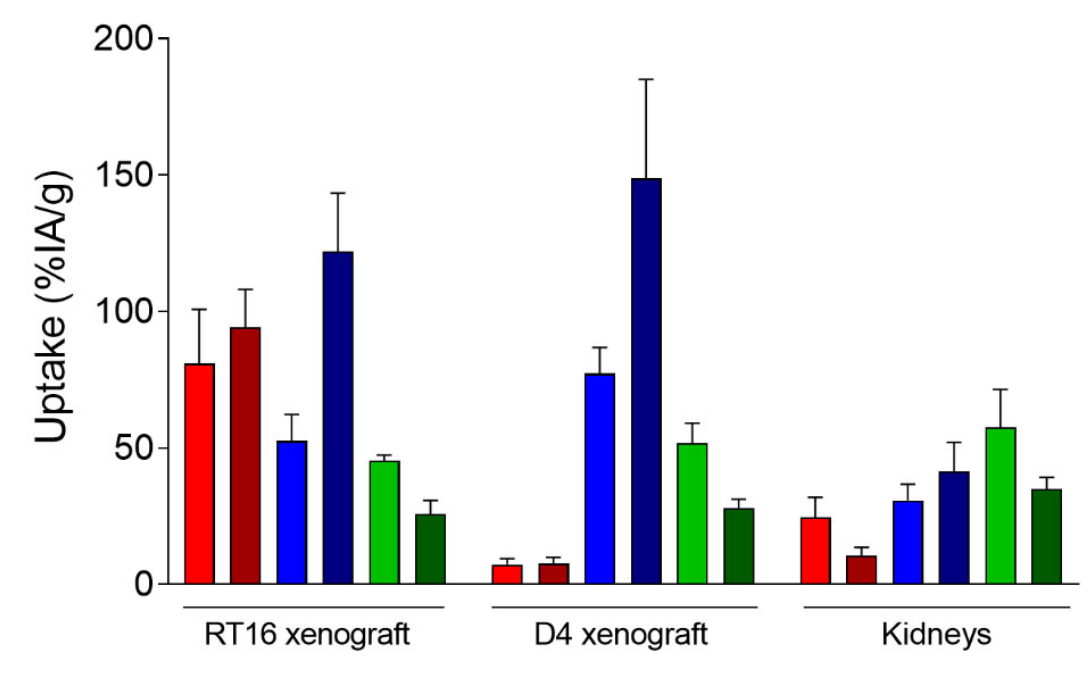

- ${ }^{18} \mathrm{~F}-6 R$-aza-5-MTHF, $1 \mathrm{~h}$ p.i.

- ${ }^{18}$ F-6S-aza-5-MTHF, 1 h p.i.

$\square \quad{ }^{18}$ F-AzaFol, 1 h p.i.

- ${ }^{18} \mathrm{~F}-6 R$-aza-5-MTHF, 3 h p.i.

- ${ }^{18}$ F-6S-aza-5-MTHF, 3 h p.i.

- ${ }^{18}$ F-AzaFol, 3 h p.i.

FIGURE 4. Graph representing the uptake of ${ }^{18} \mathrm{~F}-6 R$-aza-5-MTHF (red), ${ }^{18} \mathrm{~F}-6 S$-aza-5-MTHF (blue) and ${ }^{18} \mathrm{~F}$-AzaFol (green) in RT16 and D4 xenografts and in the kidneys at $1 \mathrm{~h}$ and $3 \mathrm{~h}$ after injection of the ${ }^{18} \mathrm{~F}$ folate radiotracers $(5 \mathrm{MBq} / \mathrm{mouse})$. 


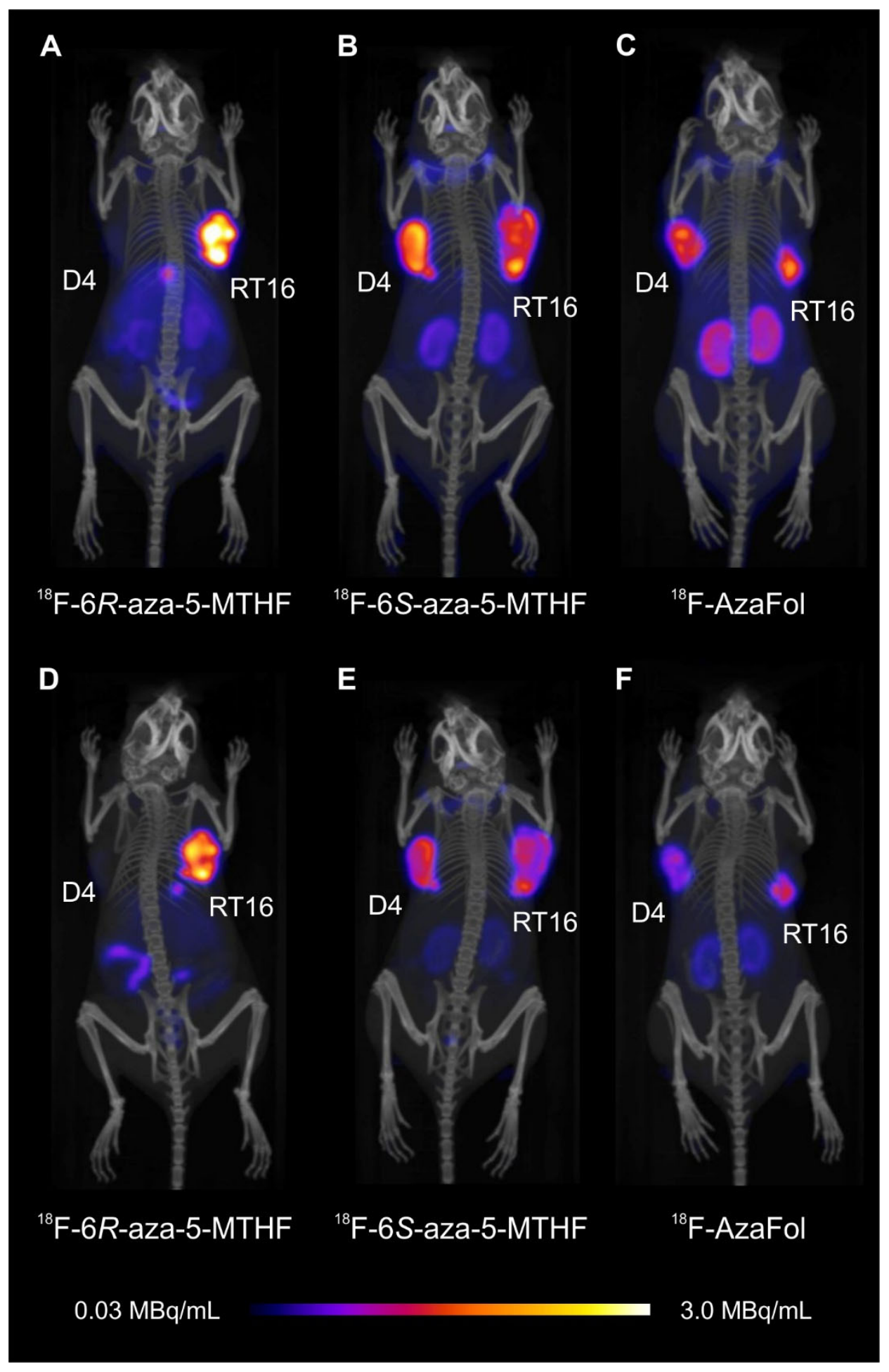

FIGURE 5. PET/CT images of mice bearing RT16 and D4 xenografts $1 \mathrm{~h}(\mathrm{~A}-\mathrm{C})$ and $3 \mathrm{~h}(\mathrm{D}-\mathrm{F})$ after injection of ${ }^{18} \mathrm{~F}$-folate radiotracers (5 MBq/mouse) shown as maximum intensity projections (MIPs). (A/D) ${ }^{18} \mathrm{~F}-6 R$-aza-5-MTHF; (B/E) ${ }^{18} \mathrm{~F}-6 S$-aza-5-MTHF and (C/F) ${ }^{18} \mathrm{~F}-\mathrm{AzaFol}(\mathrm{C} / \mathrm{F})$. 
TABLE 1. FR-Binding Affinities of Fluorinated and Non-fluorinated (Aza)-5-MTHF Derivatives Relative to ${ }^{19} \mathrm{~F}$-AzaFol or Folic Acid, respectively (set as $100 \%$ ), Determined with FR $\alpha$-expressing RT16 and FR $\beta$ expressing D4 Cells

\begin{tabular}{lcc}
\hline \multicolumn{1}{c}{ Compound } & $\begin{array}{c}\text { Relative affinity to FRo } \\
\text { (absolute binding affinity) }\end{array}$ & $\begin{array}{c}\text { Relative affinity to FR } \\
\text { (absolute binding affinity) }\end{array}$ \\
\hline${ }^{19} \mathrm{~F}-$-AzaFol & $100 \%(0.6 \pm 0.3 \mathrm{nM})$ & $100 \%(0.3 \pm 0.1 \mathrm{nM})$ \\
${ }^{19} \mathrm{~F}-6 R$-aza-5-MTHF & $34 \%(1.8 \pm 0.1 \mathrm{nM})$ & $0.3 \%(77 \pm 27 \mathrm{nM})$ \\
${ }^{19} \mathrm{~F}-6 S$-aza-5-MTHF & $29 \%(2.1 \pm 0.4 \mathrm{nM})$ & $32 \%(0.8 \pm 0.2 \mathrm{nM})$ \\
\hline Folic acid & $100 \%(0.4 \pm 0.2 \mathrm{nM})$ & $100 \%(0.3 \pm 0.1 \mathrm{nM})$ \\
$6 S-5-\mathrm{MTHF}^{*}$ & $44 \%(0.9 \pm 0.3 \mathrm{nM})$ & $0.4 \%(64 \pm 10 \mathrm{nM})$ \\
$6 R-5-\mathrm{MTHF}^{*}$ & $28 \%(1.4 \pm 0.5 \mathrm{nM})$ & $34 \%(0.8 \pm 0.4 \mathrm{nM})$ \\
\hline
\end{tabular}

* Stereochemical nomenclature of the corresponding isomers of non-fluorinated 5-MTHFs are inversed due to the different priority of substituents at the stereogenic center. 
Graphical Abstract

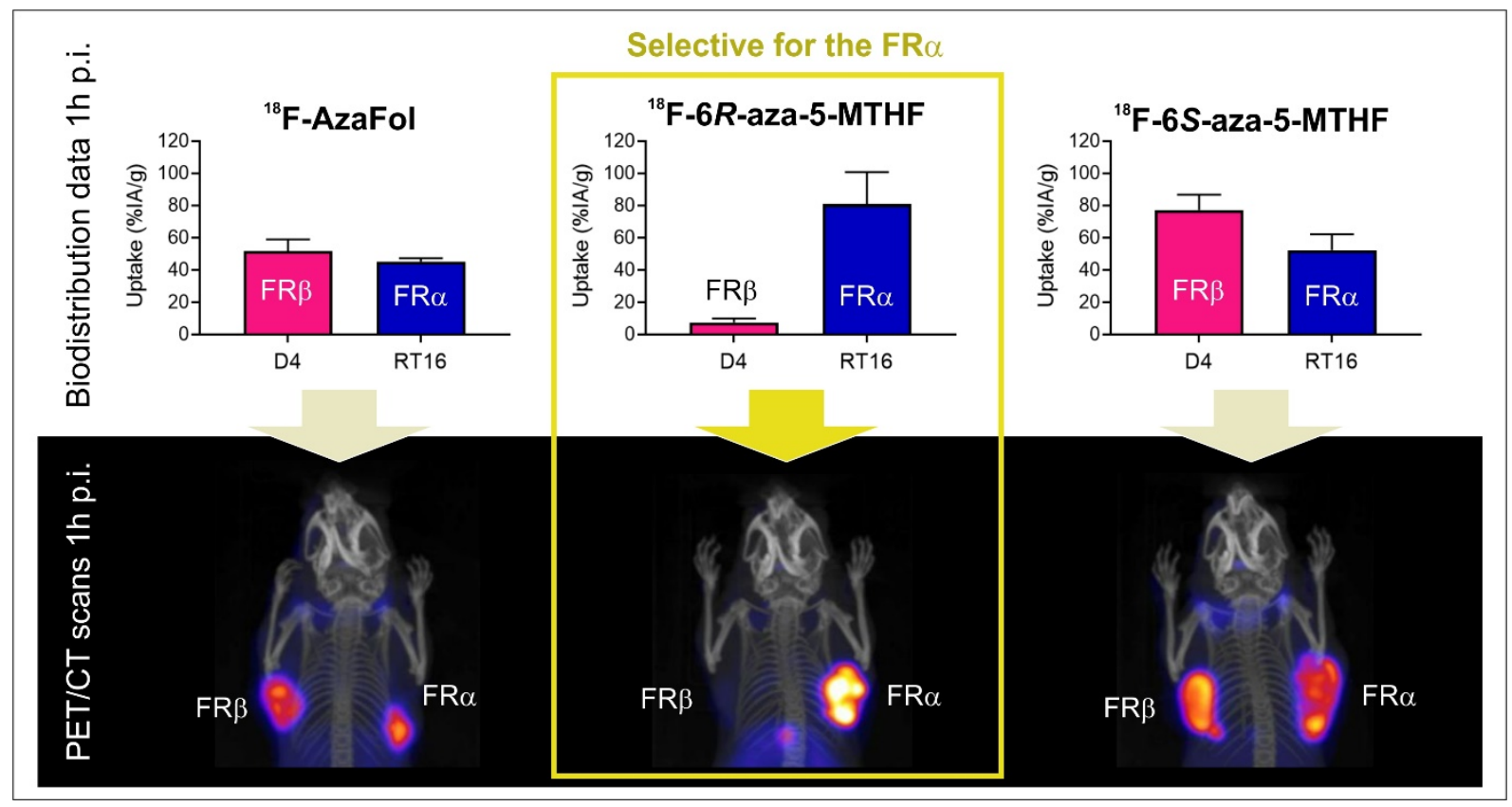




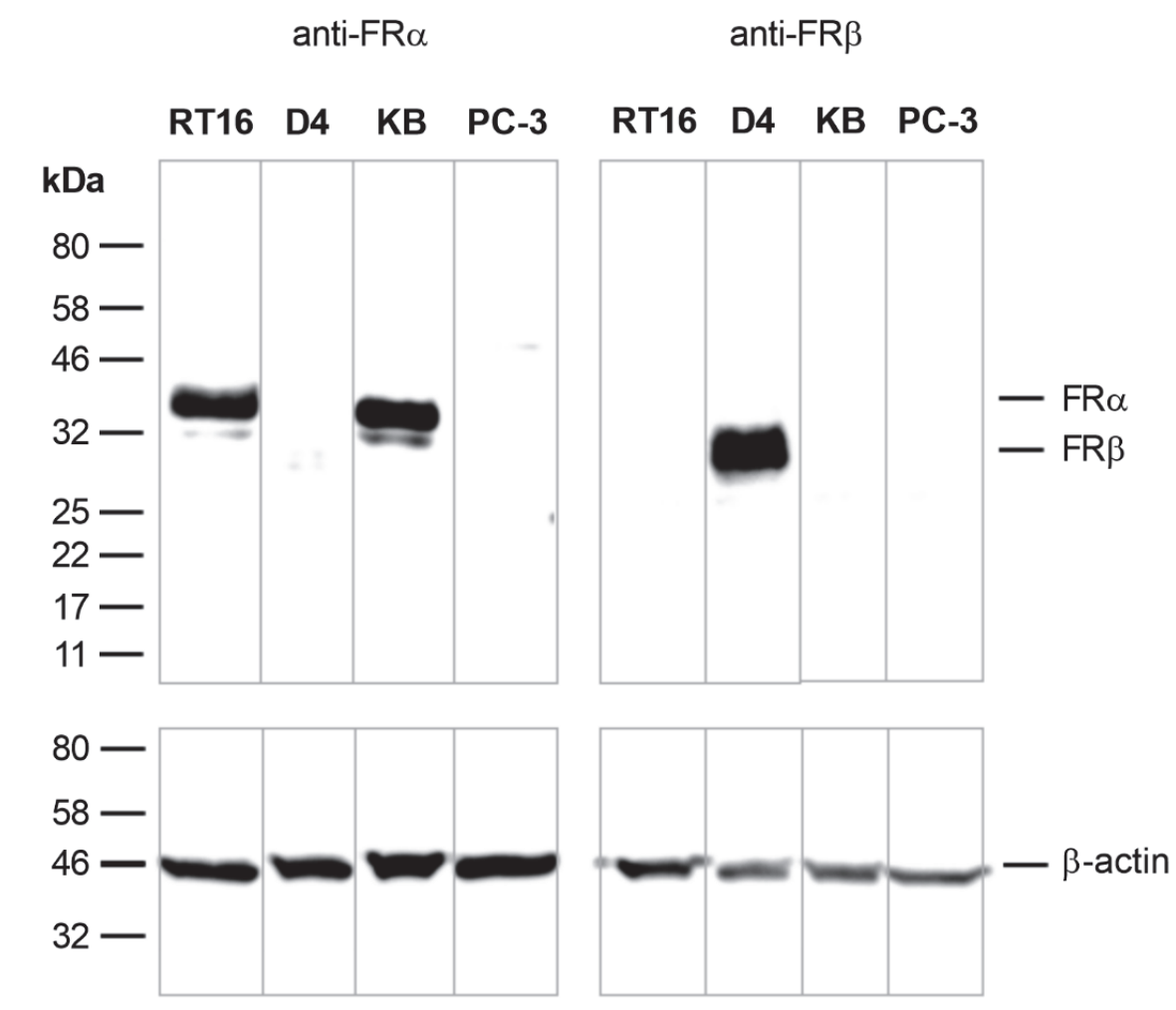

Supplemental FIGURE 1. Representative western blots demonstrating FRa ( 38 kDa) expression on RT16 cells and FR $(\sim 29 \mathrm{kDa})$ expression on D4 cells. KB and PC-3 cells were used as FRa-positive and FRa-negative controls. $\beta$-Actin staining ( $45 \mathrm{kDa})$ (bottom panel) was used as a protein loading control. 


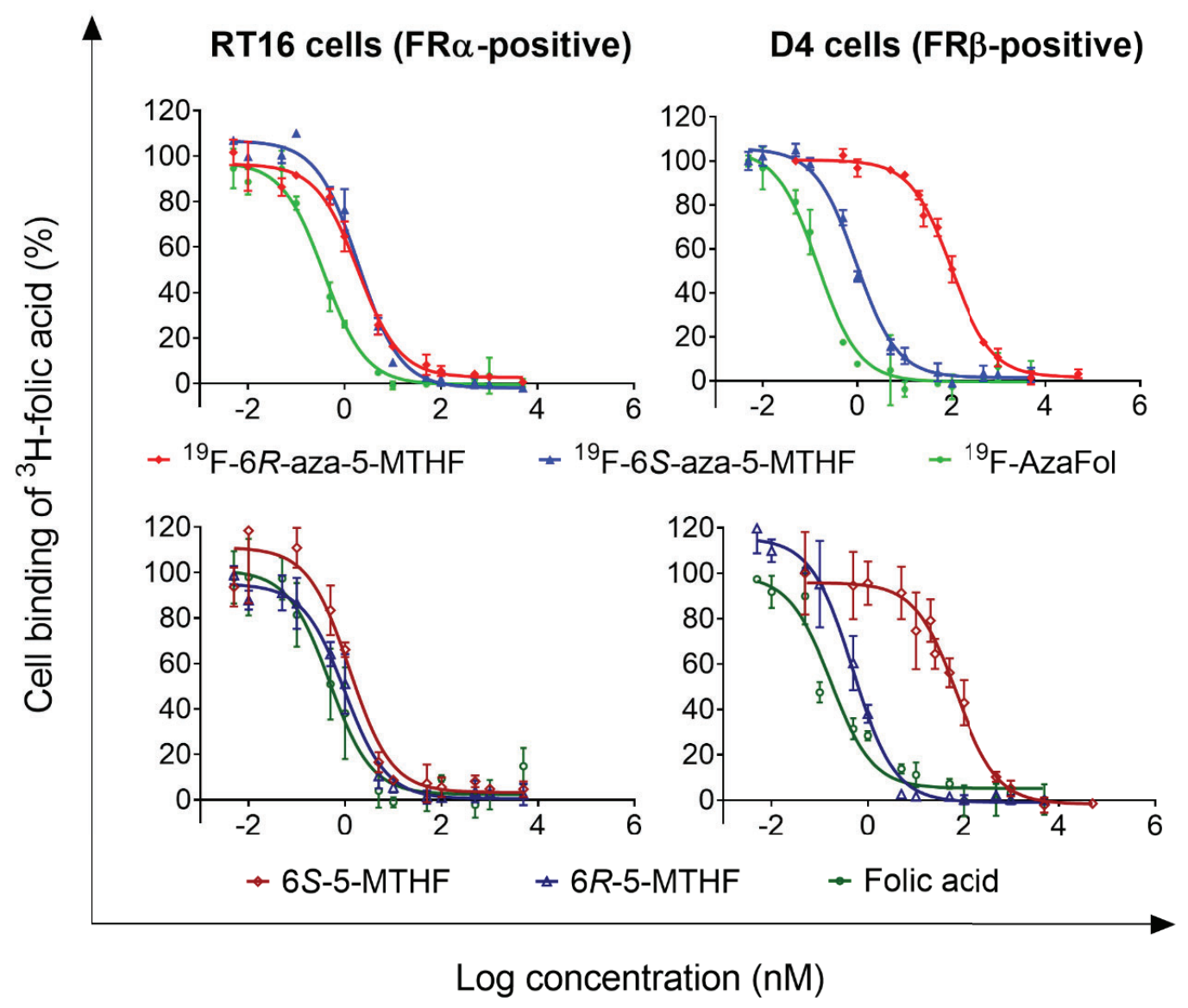

FIGURE 3. Receptor-binding curves for ${ }^{19} \mathrm{~F}-6 R$-aza-5-MTHF, ${ }^{19} \mathrm{~F}-6 \mathrm{~S}$-aza-5-MTHF and ${ }^{19} \mathrm{~F}-\mathrm{AzaFol}$ (upper panel) as well as for the non-fluorinated analogues, 6S-5-MTHF, 6R-5-MTHF and folic acid (lower panel) using ${ }^{3} \mathrm{H}$-folic acid as the radioactive tracer. The data were generated using FRa-positive RT16 cells (left panel) and FR $\beta$-positive D4 cells (right panel). 


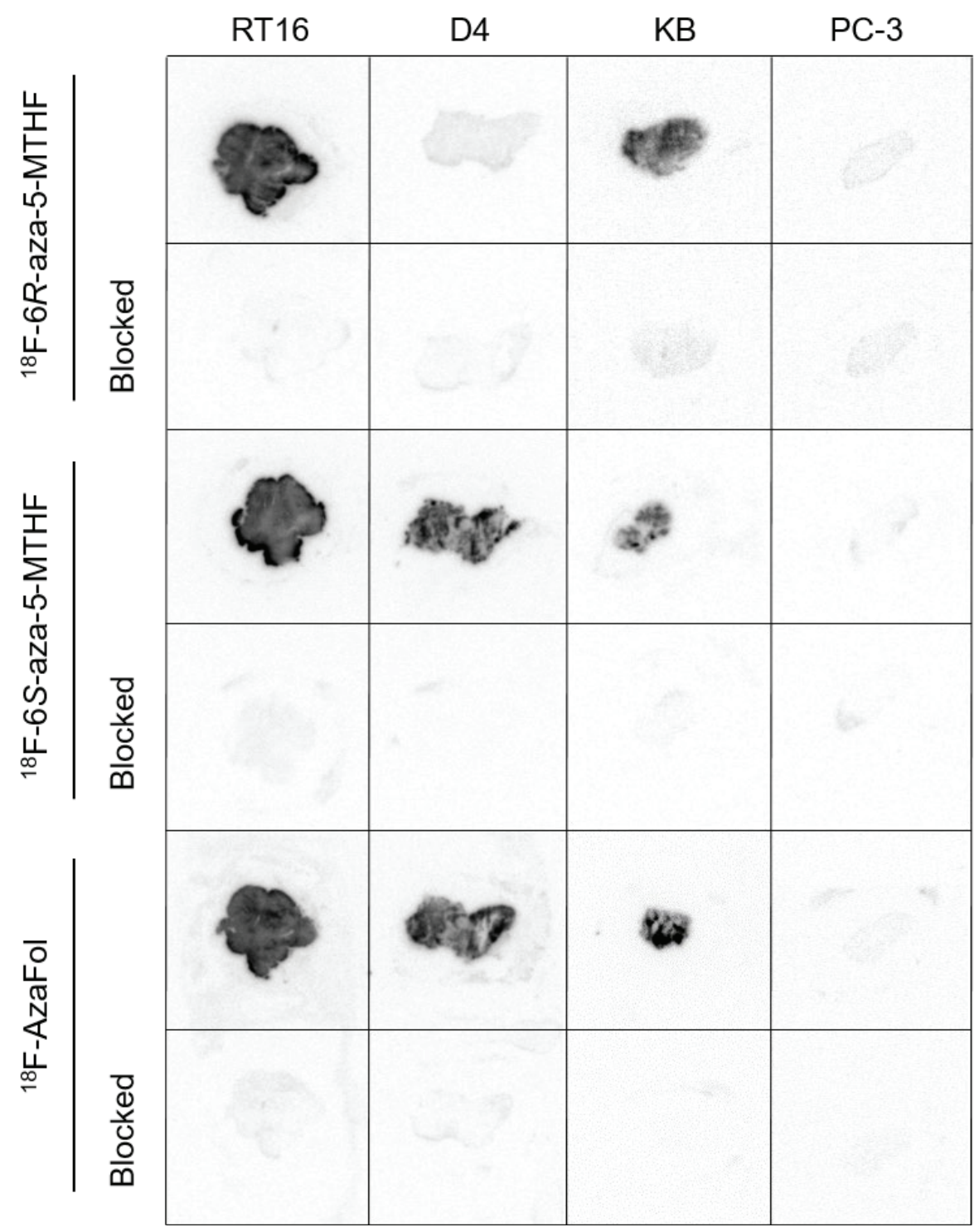

Supplemental FIGURE 3. Autoradiography images demonstrating the binding of the respective ${ }^{18} \mathrm{~F}$-folate tracer $\left({ }^{18} \mathrm{~F}-6 R\right.$-aza-5-MTHF, ${ }^{18} \mathrm{~F}-6 \mathrm{~S}$-aza-5-MTHF and ${ }^{18} \mathrm{~F}$-AzaFol, respectively) to tissue sections of FRa-positive RT16 and FRß-positive D4 xenografts as well as to tissue sections of FRa-positive KB and FR-negative PC-3 tumor xenografts. The FRs were blocked by co-incubation of the sections with excess folic acid (100 $\mu \mathrm{M})$ which prevented binding of the ${ }^{18} \mathrm{~F}$-radiotracers. 

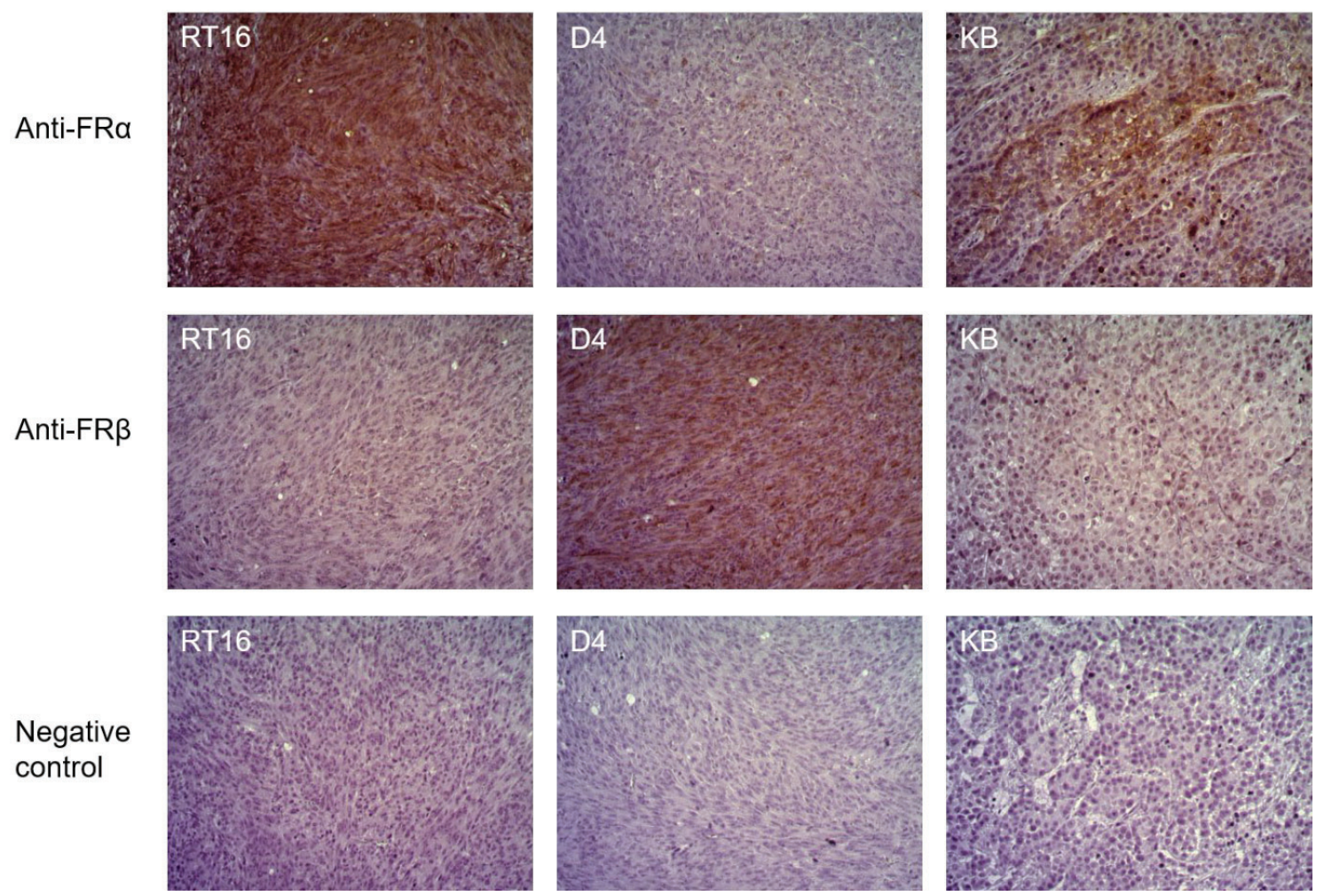

Supplemental FIGURE 4. Representative images (20x magnification) of RT16 and D4 xenograft and KB tumor xenograft sections stained by IHC using an anti-FRa-specific antibody or an anti-FRß-specific antibody. The bottom panel presents representative images of tissue sections treated without the primary antibodies to demonstrate the absence of unspecific staining by the secondary antibody. 


\section{Supplemental TABLE 1}

Concentration Range of Folate Derivatives $\left({ }^{19} \mathrm{~F}-\mathrm{AzaFol},{ }^{19} \mathrm{~F}-6 R\right.$-aza-5-MTHF, ${ }^{19} \mathrm{~F}-6 \mathrm{~S}$-aza-5MTHF) and their non-fluorinated Analogs (folic acid, 6S-5-MTHF, 6R-5-MTHF) used for Determination of the Binding Affinity ( $\mathrm{IC}_{50}$ values) to the FRa (RT16 cells) and the FR (D4 cells)

\begin{tabular}{cccc}
\hline \multirow{2}{*}{$\begin{array}{c}\text { Cell line } \\
\text { (FR isoform) }\end{array}$} & \multicolumn{3}{c}{ Folate concentration (final) $^{*}$} \\
\cline { 2 - 4 } & Folic acid & $\begin{array}{c}{ }^{19} \mathrm{~F}-\text { AzaFol/ } \\
6 \text {-aza-5-MTHF/ }\end{array}$ & $\begin{array}{c}{ }^{19} \mathrm{~F}-6 \text { S-aza-5-MTHF/ } \\
6 R-5-M T H F\end{array}$ \\
\hline RT16 (FRa) & $5 \mathrm{pM}-5 \mu \mathrm{M}$ & $5 \mathrm{pM}-5 \mu \mathrm{M}$ & $5 \mathrm{pM}-5 \mu \mathrm{M}$ \\
D4 (FR $)$ & $5 \mathrm{pM}-5 \mu \mathrm{M}$ & $50 \mathrm{pM}-50 \mu \mathrm{M}$ & $5 \mathrm{pM}-5 \mu \mathrm{M}$
\end{tabular}

*The concentration range was applied using an aliquot of cell suspension (7000 cells in $240 \mu \mathrm{L}$ PBS), the respective dilution of the folate derivative (PBS; $250 \mu \mathrm{L}$ ) and ${ }^{3} \mathrm{H}$-folic acid (41 nM; $\left.10 \mu \mathrm{L}\right)$. 


\section{Supplemental TABLE 2}

Biodistribution Data of ${ }^{18} \mathrm{~F}-\mathrm{AzaFol}$ obtained in RT16 and D4 xenograft-bearing Mice

\begin{tabular}{|c|c|c|}
\hline & \multicolumn{2}{|c|}{${ }^{18} \mathrm{~F}$-AzaFol } \\
\hline & \multicolumn{2}{|c|}{ Biodistribution data } \\
\hline & 1 h p.i. & 3 h p.i. \\
\hline & $(\% \mathrm{IA} / \mathrm{g})$ & $(\% \mathrm{IA} / \mathrm{g})$ \\
\hline Blood & $0.69 \pm 0.06$ & $0.57 \pm 0.04$ \\
\hline Lung & $2.1 \pm 0.2$ & $1.9 \pm 0.3$ \\
\hline Spleen & $2.0 \pm 0.2$ & $6.2 \pm 0.6$ \\
\hline Kidneys & $58 \pm 14$ & $35 \pm 4$ \\
\hline Stomach & $2.2 \pm 0.2$ & $2.1 \pm 0.3$ \\
\hline Intestines & $2.0 \pm 0.5$ & $2.8 \pm 0.5$ \\
\hline Liver & $7.4 \pm 0.3$ & $11 \pm 1$ \\
\hline Salivary glands & $11 \pm 1$ & $13 \pm 1$ \\
\hline Muscle & $1.8 \pm 0.2$ & $1.2 \pm 0.2$ \\
\hline Bone & $1.6 \pm 0.2$ & $1.4 \pm 0.2$ \\
\hline Brain & $0.92 \pm 0.09$ & $1.2 \pm 0.1$ \\
\hline RT16 xenograft & $45 \pm 2$ & $26 \pm 5$ \\
\hline \multirow[t]{3}{*}{ D4 xenograft } & $52 \pm 7$ & $28 \pm 3$ \\
\hline & \multicolumn{2}{|c|}{ Xenograft-to-background ratios } \\
\hline & 1 h p.i. & 3 h p.i. \\
\hline RT16-to-blood & $66 \pm 8$ & $45 \pm 7$ \\
\hline D4-to-blood & $74 \pm 4$ & $49 \pm 6$ \\
\hline RT16-to-liver & $6.1 \pm 0.5$ & $2.3 \pm 0.3$ \\
\hline D4-to-liver & $6.9 \pm 0.7$ & $2.5 \pm 0.3$ \\
\hline RT16-to-kidney & $0.81 \pm 0.14$ & $0.74 \pm 0.10$ \\
\hline D4-to-kidney & $0.94 \pm 0.30$ & $0.81 \pm 0.07$ \\
\hline
\end{tabular}

Values shown represent the mean \pm S.D. of data obtained from $n=3-4$ mice per cohort.

Xenograft-to-background ratios were calculated for blood, liver and kidneys. 


\section{Supplemental TABLE 3}

Biodistribution Data of ${ }^{18} \mathrm{~F}-6 R$-aza-5-MTHF obtained in RT16 and D4 Xenograft-bearing Mice

\begin{tabular}{|c|c|c|}
\hline & \multicolumn{2}{|c|}{${ }^{18} \mathrm{~F}-6 R$-aza-5-MTHF } \\
\hline & \multicolumn{2}{|c|}{ Biodistribution data } \\
\hline & 1 h p.i. & 3 h p.i. \\
\hline & $(\% \mathrm{IA} / \mathrm{g})$ & $(\% \mathrm{IA} / \mathrm{g})$ \\
\hline Blood & $2.4 \pm 0.5$ & $0.68 \pm 0.20$ \\
\hline Lung & $3.3 \pm 0.7$ & $2.2 \pm 0.6$ \\
\hline Spleen & $17 \pm 6$ & $26 \pm 7$ \\
\hline Kidneys & $25 \pm 7$ & $11 \pm 3$ \\
\hline Stomach & $3.0 \pm 1.0$ & $2.1 \pm 0.7$ \\
\hline Intestines & $8.3 \pm 1.4$ & $8.1 \pm 3.5$ \\
\hline Liver & $16 \pm 3$ & $13 \pm 4$ \\
\hline Salivary glands & $7.4 \pm 1.7$ & $6.6 \pm 2.5$ \\
\hline Muscle & $1.8 \pm 0.4$ & $0.97 \pm 0.24$ \\
\hline Bone & $2.3 \pm 0.5$ & $2.5 \pm 0.5$ \\
\hline Brain & $1.7 \pm 0.6$ & $2.3 \pm 0.5$ \\
\hline RT16 xenograft & $81 \pm 20$ & $94 \pm 14$ \\
\hline \multirow[t]{3}{*}{ D4 xenograft } & $7.3 \pm 2.1$ & $7.6 \pm 2.3$ \\
\hline & \multicolumn{2}{|c|}{ Xenograft-to-background ratios } \\
\hline & $1 \mathrm{~h} \mathrm{p.i.}$ & 3 h p.i. \\
\hline RT16-to-blood & $35 \pm 10$ & $145 \pm 37$ \\
\hline D4-to-blood & $2.7 \pm 0.8$ & $11 \pm 1$ \\
\hline RT16-to-liver & $5.1 \pm 1.5$ & $7.5 \pm 1.2$ \\
\hline D4-to-liver & $0.40 \pm 0.10$ & $0.59 \pm 0.11$ \\
\hline RT16-to-kidney & $3.5 \pm 1.3$ & $9.3 \pm 1.5$ \\
\hline D4-to-kidney & $0.28 \pm 0.10$ & $0.73 \pm 0.11$ \\
\hline
\end{tabular}

Values shown represent the mean \pm S.D. of data obtained from $n=4$ mice per cohort. Xenograft-to-background ratios were calculated for blood, liver and kidneys. 


\section{Supplemental TABLE 4}

Biodistribution Data of ${ }^{18} \mathrm{~F}-6 \mathrm{~S}$-aza-5-MTHF obtained in RT16 and D4 Xenograft-bearing Mice

\begin{tabular}{|c|c|c|}
\hline & \multicolumn{2}{|c|}{${ }^{18} \mathrm{~F}-6 S$-aza-5-MTHF } \\
\hline & \multicolumn{2}{|c|}{ Biodistribution data } \\
\hline & $1 \mathrm{~h} \mathrm{p.i.}$ & 3 h p.i. \\
\hline & $(\% \mathrm{IA} / \mathrm{g})$ & $(\% \mathrm{IA} / \mathrm{g})$ \\
\hline Blood & $1.5 \pm 0.4$ & $1.2 \pm 0.1$ \\
\hline Lung & $2.4 \pm 0.5$ & $2.3 \pm 0.2$ \\
\hline Spleen & $3.0 \pm 0.5$ & $2.9 \pm 0.4$ \\
\hline Kidneys & $31 \pm 6$ & $41 \pm 11$ \\
\hline Stomach & $2.1 \pm 0.6$ & $2.0 \pm 0.2$ \\
\hline Intestines & $2.6 \pm 0.4$ & $2.1 \pm 0.4$ \\
\hline Liver & $5.5 \pm 0.6$ & $4.0 \pm 0.5$ \\
\hline Salivary glands & $15 \pm 2$ & $23 \pm 4$ \\
\hline Muscle & $1.4 \pm 0.2$ & $1.4 \pm 0.4$ \\
\hline Bone & $1.4 \pm 0.1$ & $1.4 \pm 0.2$ \\
\hline Brain & $1.6 \pm 0.4$ & $3.1 \pm 0.1$ \\
\hline RT16 xenograft & $53 \pm 10$ & $122 \pm 21$ \\
\hline \multirow[t]{3}{*}{ D4 xenograft } & $77 \pm 10$ & $149 \pm 36$ \\
\hline & \multicolumn{2}{|c|}{ Xenograft-to-background ratios } \\
\hline & $1 \mathrm{~h}$ p.i. & 3 h p.i. \\
\hline RT16-to-blood & $37 \pm 10$ & $105 \pm 13$ \\
\hline D4-to-blood & $50 \pm 5$ & $127 \pm 24$ \\
\hline RT16-to-liver & $9.5 \pm 1.0$ & $30 \pm 3$ \\
\hline D4-to-liver & $15 \pm 2$ & $37 \pm 5$ \\
\hline RT16-to-kidney & $1.7 \pm 0.2$ & $3.0 \pm 0.5$ \\
\hline D4-to-kidney & $2.8 \pm 0.9$ & $3.6 \pm 0.3$ \\
\hline
\end{tabular}

Values shown represent the mean \pm S.D. of data obtained from $n=4$ mice per cohort. Xenograft-to-background ratios were calculated for blood, liver and kidneys. 